\title{
ВЕРБАЛІЗАЦІЯ СОЦІАЛЬНО-ПСИХОЛОГІЧНОГО ФЕНОМЕНА МЕДІАОБРАЗІВ У ДИСКУРСІ СУЧАСНОЇ УКРАЇНСЬКО- Й РОСІЙСЬКОМОВНОЇ ГАЗЕТИ: АКТУАЛІЗАЦІЯ АСОЦІАТИВНИХ ЗВ’ЯЗКІВ
}

У наш час газетний дискурс найбільш послідовно відображає рівень духовності нації, іï спосіб мислення. Актуалізація вторинних засобів номінації - постійна мовна тенденція, що демонструє прагнення до виразності, конденсачї інформації та привабливості медіатексту. Комбінаторність лексем зумовлена набором певних семантичних і прагматичних стереотипів, які демонструють, що повсякденна свідомість мовия базується на асоціаціях, а не на енциклопедичних знаннях. Під час моделювання медіаобразів політиків, а також вербалізації процесів та явищ, що проявляються в сукупності фрагментів медіа-дискурсу, виникають концептуалізовані метафори, які розглядаємо як соціально-психологічний феномен.

Ключові слова: асоціація, дискурс, вторинні засоби номінаціі, семантика, прагматика, медіа-образ політика, метафора, соціально-психологічний феномен, стереотип.

Kosmeda T. Verbalization of Socio-Psychological Phenomenon of Media Images in the Modern Ukrainian and Russian Newspaper Language: Actualization of Associative Links. Nowadays, newspaper language most consistently reflects the level of nation's spirituality, its mentality, the way of thinking, specifically some political and socio-cultural interests as well as verbalized stereotypes which are based on associative links of consciousness. The usage of secondary nomination means can be considered as a constant tendency that demonstrates the desire for expressiveness, information condensing and attractiveness of a media text.

The purpose of the article is to show the associative potential of the human psyche for media images modelling, drawing attention to the semantic stereotypes that manifest themselves in the process of rethinking of certain musical terms.

The conclusions drawn from the analysis show that the combinatoriality of lexical units that are used in the newspaper language is caused, in particular, by a set of unsophisticated semantic stereotypes at the semantic and pragmatic levels. In the process of linguistic units modelling, the features, which are first and foremost fixed in the speaker's everyday consciousness and are based mainly on associations and not on the basis of encyclopedic knowledge, are carried into effect. The conceptualized metaphorical images reflect a socio-psychological phenomenon, which primarily describes the media images of politicians, as well as the processes and phenomena revealed in the aggregate of discursive media fragments formed in linguistic practice 
and based on established universal and national stereotypes and motivated by the link of typical associations.

Keywords: association, discourse, means of secondary nomination, semantics, pragmatics, media image of a politician, metaphor, socio-psychological phenomenon, stereotype.

\section{Вступ}

Дослідження мови засобів масової інформації в останні роки привертає прискіпливу увагу мовознавців, що актуалізується, зокрема, крізь призму медіалінгвістики, психолінгвістики й політичної лінгвістики. Своєрідність розвитку української медіалінгвістики докладно описала Л. Шевченко, яка наголосила, що «в комплексі медіалінгвістичних проблем як інтегрального гуманітарного знання важливо зосередити увагу на мовознавчій аспектології, що й визначає один зі складників цього синкретичного поняття. Очевидно, ідеться про вербалізовану дійсність, представлену в медіа. Вербалізація дійсності в такому разі передбачає загальний, рівневий і компонентний аналіз мовних засобів, що функціюють у цій комунікативній сфері» (Шевченко, 2014: 172). Лінгвісти вивчають і фіксують не лише ознаки та механізми, що характерні для політичного мовлення, відображеного в 3MI, але й процеси змін, що відбуваються в лінгвокультурній свідомості мовних особистостей. Прийоми, стратегії і тактики, що реалізуються через політичний дискурс, політичне мовлення, номінації, що стосуються імен політичних лідерів, подій, процесів, зумовлені низкою чинників: це й глобальні суспільно-історичні зміни останніх десятиліть, і стрибкоподібний ріст інформаційно-комунікативних технологій, і формування єдиного інформаційного простору (див. Космеда, 2017).

За допомогою мови політичні суб'єкти досягають своєї мети, тому іiі, що очевидно, уважають основним інструментом політичної діяльності. За їі допомогою маніпулюють свідомістю людей, оскільки лінгвоментальні стереотипи інтерпретують як «особливі мисленнєві структури, що зберігаються у свідомості при сприянні мовного знака» (Чернявская, 2006: 53). Ці стереотипи інколи нав'язуються суспільству, зокрема й через 3MI, насамперед частотністю їх уживання, залученням нових привабливих моделей, незвичних мовних форм (див. Космеда, 2014a). 
Абсолютно слушною є думка, що мова ЗМІ - «одна з найбільш впливових сфер мови. Із часом вплив цієї мови не зменшується, а, навпаки, збільшується. Художнє, наукове, офіційне мовлення за ступенем впливу на літературну мову не можна порівняти з масовою комунікацією. Маючи величезну авдиторію, різноманітні засоби інформування і впливу, мова 3МІ стає центром національної мови» (Язык СМИ и политика, 2012: 8). 3МІ дають панорамну картину тенденцій розвитку кожної мови, викликають суперечливі судження й оцінки про те, що відбувається. Саме 3MI, зокрема й мова газети, стають законодавцями мовної моди, вихователями мовного смаку. 3МІ творять основу комунікації в масовій культурі та визначають іiі характер. Вирішальний атрибут 3МI - це, як наголошувалося, надрегіональний, загальнонаціональний характер і глобальний діапазон (див. Степаненко, 2018). Мова «покликана все документувати, зберігати в просторі й часі, передавати від покоління до покоління продуковану інформацію. Вона з педантичною точністю зафіксовує сьогодні українські феномени...» (Степаненко, 2017: 49). Зміст, переказаний через 3MI, має публічний характер. Він скерований до всіх, кого може зацікавити. Основними образними засобами 3МI справедливо вважають метафору, перифразу, феномен прецедентності, що своєрідно проєктується й на власні назви, імена політиків (див. Космеда, 2014b), моделюючи відповідні медіаобрази.

Мета цієї наукової студії - показати асоціативний потенціал людської психіки для моделювання медіаобразів, спроєктувавши увагу на семантичні стереотипи, що виявляються під час переосмислення деяких музичних термінів. Відповідно до поставленої мети передбачаємо розв’язання таких завдань: 1) висвітлити особливості функціювання семантичних стереотипів як основи для метафоричних переосмислень; схарактеризувати аспекти їх дослідження в сучасній лінгвістиці; 2) описати особливості метафоризації деяких музичних термінів (голос, диригент, музика), що слугують, зокрема, для характеристики політичних лідерів.

Дослідницький матеріал - сучасні українсько- й російськомовні газети: «Голос України», «Україна молода», «Українська правда», «Слово просвіти», «Like», «Комсомольская правда», «Известия», «Российская газета», «Труд», «Обозреватель», а також словник метафоричних словосполучень української преси О. Ільченко (Ільченко 2012: далі - СI). 


\section{Методи дослідження}

У процесі дослідження було застосовано метод лінгвістичного спостереження, описовий метод (прийоми внутрішньої та зовнішньої інтерпретаціі), концептуальний і компонентний аналізи; психолінгвістичний метод вияву семантичних стереотипів та асоціацій, на основі яких змодельовано механізми творення метафори, метонімії, перифрази, актуалізації прецедентності, а також вияв оцінного характеру мовної одиниці; метод дослідницького абстрагування для кваліфікації ознак мовних одиниць, що становлять фактичний матеріал.

\section{Виклад основного матеріалу}

Наголосімо, що теорію семантичних стереотипів активно розробляли французькі дослідники (Ж.-Кл. Анскомбр, О. Дюкро, Дж. Клейбер, Ж.-М. Маранден, Б. Фраден). Саме вони ввели поняття асоціативної анафори, анафоричних відношень, що виникають у мовній свідомості. Анафоричним традиційно уважають вислів, що скеровує мовця до відомого явища, події, ситуації, зокрема й імені, тобто до того, що вже є в пам'яті носія мови - текстуальній (дискурсивній) чи ситуативній, тобто те, що базується на прецедентності. Семантичний стереотип у мовознавстві традиційно розглядають як відтворювану мовну формулу - це, звісно, система паремій: усталені сполучення слів, ідіоми, прислів'я, приказки, формули ввічливості, лайливі вислови, слогани та ін. Крім того, складні метафоричні моделі також Ірунтуються на відповідних семантичних стереотипах та асоціаціях. Семантичний стереотип - це, як відомо, усталений, емоційно забарвлений ментальний образ. На основі актуалізації ментального стандартизованого способу концептуалізації довкілля відбувається мовне втілення концепту - певного образу чи уявлення про предмет, що відбувається на основі актуалізації системи асоціативних зв'язків.

Мовознавці досліджують залежність метафоричних утворень від семантичних стереотипних ознак слова, частина значення якого підлягає метафоричному переосмисленню; виявляють зв'язки між конотацією та стереотипом; групують стереотипи за лексико-семантичними групами, семантичними полями, ураховуючи й емоційно-оцінні характеристики слів чи словосполучень. Значну частину питань, пов'язаних із семантичними стереотипами, вивчають крізь 
призму етнолінгвістики. Дослідники, які розробляють проблематику етнолінгвістики (Є. Бартмінський, О. Селіванова, I. Голубовська та ін.), а також політичної лінгвістики (Н. Кондратенко, М. Навальна, Л. Синельникова, М. Степаненко, О. Стишов та ін.), наголошують, що семантичні стереотипи грунтуються на двох особливостях людської свідомості: з одного боку, прагненні до конкретизації, тобто абстрактні уявлення пов'язуються з конкретними образами, а з другого, - на тенденції до спрощення, тобто до виокремлення кількох ознак як провідних для позначення складних явищ із урахуванням відповідних типових асоціацій. Є. Бартмінський зауважує, що «процеси стереотипізації охоплюють думки й висловлювання, які стосуються людей, а також думки про предмети й події» (Бартминьский, 2009: 12). Цей дослідник розмірковує про елементарні стереотипні судження, які підсвідомо приписують усім об’єктам класу, згрупованого за допомогою відповідної мовної одиниці (див. Бартминьский, 2005). Учений наголошує, що «центральною частиною змісту стереотипів $€$ описові ознаки (пізнавальні), іноді маргінальні й несуттєві, але такі, що суб'єктивно підносяться до рангу типових; описовий зміст супроводжує інтелектуальна й соціальна оцінка» (Бартминьский, 2009: 15). Стало аксіомою твердження, що семантичні стереотипи базуються на культурних концептах. Ці концепти отримують відповідну соціальну оцінку, яку можемо розмістити на шкалі оцінки для вияву ії характеру, тенденційності (див. Космеда, 2000). Процес метафоризації сприяє доповненню картини світу, зокрема й мовної. На цій основі може здійснюватися певне програмування мовної поведінки в межах відповідної лінгвокультурної спільноти.

Політично ідеологізоване мовлення оперує стереотипними ознаками слів, щоб поєднати навіть такі поняття, які зазвичай мало пов'язані між собою. У процесі такого асоціативного зближення одну з головних ролей відіграє, як наголошувалося, метафора. У ракурсі цього дослідження актуальним уважаємо тлумачення метафори, яке запропонувала Н. Арутюнова: «...це транспозиція ідентифікувальної (дескриптивної й семантично дифузної) лексики, що призначена для вказівки на предмет мовлення, скерована у сферу предикатів, які слугують для виокремлення його ознак і властивостей» (Арутюнова, 1990: 19). У словнику може бути й не зафіксоване переносне, метафоричне вживання тієї чи тієї лексеми, а в дискурсі, репрезентованому в 3MI, 
через актуалізацію стереотипних семантичних ознак лексема отримує активне поширення як одиниця метафоричного переосмислення, що посилює чи послаблює позитивні чи негативні характеристики, які приписують предмету (особі) в межах певної лінгвокультури, певного соціуму. Отже, метафора базується на семантичних стереотипах, асоціаціях, що актуалізуються безпосередньо в сучасному дискурсі, а політичні й ідеологічні структури грунтуються на протиставленні, боротьбі ідей і стереотипів, що їх репрезентують.

Існує думка, що використання вторинних імен «можливе лише в умовах культурної спільноти членів конкретного соціуму, які володіють певною сукупністю знань, уявлень, асоціацій, що становлять лексичне тло конкретної словесної одиниці» (Кульпина, 2002: 180). Саме метафори-перифрази дуже активні в сучасних 3МI як описові конструкції, що замінюють собою назви предметів, явищ, осіб і т. ін. Вони виражають оцінку предмета чи особи, що називають і навіюють певні політичні або соціальні установки, тому їх і вважають важливим засобом маніпуляції людською свідомістю. Імена політиків - об’єкт найбільш активних метафоризацій і перифразування. Перифрази на позначення політичних суб'єктів не лише номінують, але й надають яскраву оцінювальну характеристику, виокремлюючи найбільш важливі риси особистості. Зрозуміло, що для сприйняття оцінки, експресивності, емоційних виявів необхідно володіти певними фоновими знаннями, так званим вертикальним контекстом, розуміти політичну ситуацію, мати відомості про політичну діяльність того чи того політика й под.

Метафору й перифразу сьогодні розглядають не лише як орнаментальні одиниці мови, окрасу мовлення, художні тропи, риторичні одиниці, але і як спосіб вербалізації думок, емоцій, інтенцій, асоціацій і под. Метафора, зокрема й метафора-перифраза, - наслідок складного мисленнєво-мовленнєвого процесу, що базується на чиннику емоційної й інтелектуальної напруги.

Унаслідок детермінологізації, як показує зібраний матеріал, активно метафоризується термін голос, що моделює і позитивні, і негативні смисли, «ковзаючи» по шкалі оцінки. Ця модель творення метафори полягає в тому, що вона накладається на метонімію. В авторській картотеці є зразки метафоризації терміна диригент та деяких інших, що проаналізуємо нижче. 
Наведемо російськомовні приклади метафоризації лексеми голос з позитивними смислами: голос памяти - це 'вияв пам'яті, спогадів про когось або про щось’: Голос памяти: оперные звёзды посвятили кониерт Дмитрию Хворостовскому (И., 17.10.2018, 1). Простежуємо сполучуваність іменника рос. голос з абстрактними іменниками (рос. память) і з іменниками конкретної семантики (рос. поколение), напр.: голос поколения - 'про думки, погляди, переконання конкретної соціальної й вікової групи на конкретну проблему' (функціює в назві статті - И., 16.10.2018, 2); голос Запада и Центра - 'про пряме висловлювання думок і переконань, здійснене в певних регіонах, на певних територіях, у певних організаціях тощо', порівн.: Голос Запада и Центра страны прозвучал громко и результативно на киевском майдане: самопровозглашенная власть пользуется существенной поддержкой именно в этих макрорегионах Украины (И., 23.05.2014), а також голос ООН: Но ведь и голос ООН некоторые западные державы в военных конфликтах предпочитают игнорировать... (КП, 22.05.2014).

Трапляється чимало українськомовних прикладів функціювання лексеми голос з позитивною семантикою: так називають, напр., відомого українського актора Євгена Нищука, який виконував функції ведучого на Майдані, зокрема й під час Революції Гідності (2014), а після революції він був призначений Міністром Культури України.

Лексему голос уживають, як бачимо, з прецедентними іменами, зокрема такими, як Майдан, що став в Україні символічною назвою всього передового, позитивного, креативного; при цьому метафоричне словосполучення може братися в лапки, що додатково вказує на актуалізацію переносного значення лексеми, але лапки використовують непослідовно, оскільки для цього не вироблено відповідних правил, напр.: «голос Майдану»: Його називають «голосом Майдану» (ГУ, 17.01.2014). Оскільки Євген Нищук виконував функції ведучого й під час Майдану в 2006 році, іноді його називають «голосом двох майданів»: Талановитий актор... «голос двох Майданів»... (ГУ, 30.11.2015). Спостерігаємо й такі модифікації вживання метафоричних словосполучень, як «голос Майдану» 2004-го року: Поряд стоіть «голос Майдану» 2004-го року - тодішній і нинішній модератор, актор Євген Нищук. Глибоко символічно, що він став голосом і иього Майдану (ПУ, 17.01.2014); голос революцї: Мене нині називають по-різному - голос револючї, обличчя Майдану... (ГУ, 23.11.2006), 
«голос» Помараниевої революиіи: Євгена Нимука, 33 роки, називають «голосом» Помараниевої революиії (ГУ, 23.11.2006). Натрапляємо й на «голос сцени свободи»: "Голос сиени свободи», він двічі вів країну на боротьбу за гідність, покинувши заради иього театральні підмостки (ГУ, 23.11.2006); наш Голос: Ми не могли не послухатись Євгена, бо наш Голос сам був взірием відваги (Like, 23.11.2015). В останньому прикладі метафора голос функціює в написанні з великої літери, актуалізовано прийом капіталізації, а поєднання ії з присвійним займенником наш інтимізує вислів.

У 2019 році з'явилася політична партія С. Вакарчука, назвою якої також стала містка за прагматикою, здатністю активно моделювати асоціативні семантичні ряди лексема голос. У політичних рекламах цієї партії було простежено наповнення слова-назви низкою смислів, вербалізуються потенційні концепти, що грунтуються й на антиноміях, протиставленні, напр.: ...беззвучна Верховна Рада, але з'являється голос, щзо висловлює те, що потрібно народу; старі політики поставили крайну на беззвучний режим. Пора повернути краӥні голос (з усного мовлення) та ін.

Іноді поруч із метафорою голос з'являється й метафора обличчя. Вище вже було наведено приклад щодо Євгена Нищука («обличчя Майдану»), але в авторській картотеці є зразки, де йдеться про Руслану Лижичко - популярну українську співачку, яка активно підтримувала Помаранчеву революцію й відзначилася як політичний лідер відповідного українського історичного періоду, - обличчя $\boldsymbol{i}$ голос Майдану: Від першого дня на Майдані співачка Руслана Лижичко [...] стала обличчям і голосом Майдану (УМ, 26.11.2004).

Прикладів, у яких простежуємо негативні смисли, вербалізовані лексемою голос, зокрема й іронічні, більше. Це мотивовано й поширеністю асоціацій, що проєктуються на поєднання слова голос із прізвищами відомих політиків, передусім колишніх Президентів України, до яких у народу були певні претензії. Ідеться, зокрема, про Леоніда Кучму й Віктора Януковича, порівн.: «голос Кучми» - 'про плівки із записами, на яких зафіксовано мовлення Леоніда Кучми - другого Президента України'. Напр.: У Ющенка готові судитися із «голосом Кучми» (ГУ, 13.10.2006), а також «двічі несудимий» голос Донбасу. Відомо, що Віктор Янукович був справді двічі судимим, а голосом Донбасу його називали, оскільки він народився на Донбасі й там починав 
свою політичну кар'єру, мешканці Донбасу були його основним електоратом, який вирізнявся антиєвропейськими настроями й поглядами, порівн.: Під яким стягом прийшов до влади «двічі несудимий» голос Донбасу? (СП, 08.14.09.2016).

Іронію може репрезентувати й прецедентний вислів золотий голос, що має позитивне значення - характеризує людину з надзвичайними здібностями в співі. Цей фразеологізм доповнюють певними компонентами для моделювання негативного смислу, порівн.: «золотий голос» ПР. Негативне значення привносить і вислів пронизливий голос, напр.: Його вмілі руки диригують голосуванням у Верховній Раді, його пронизливий голос, який називають «золотим голосом» ПР, знає вся краӥна (ПУ, 09.07.2012) - 'про одного з представників Партії Регіонів, який у прямому розумінні керував голосуванням Партії Регіонів' (тут удало актуалізовано словесну опозицію 'голосування - голос'). Виглядало це так: депутат вставав і, ніби диригентською паличкою, махав рукою за потреби одностайного голосування, тому в мові газети з'явилися метафори з актуалізацією лексеми укр. диригент і рос. дирижёр. Порів.: укр. відомий диригент «тушок» (О., 15.01.2013); диригент парламентського хору (С., 10.08.12); диригент «піаністів" у Верховній Раді (УП, 22.08.2012) чи «Заслужений диригент» (Т., 09.01.2014). Простежуємо мовну гру, маніпуляцію мовними засобами, що базується на трансформації одиниць, за якими закріплені позитивні смисли (золотий голос, Заслужений диригент), в одиниці з негативною семантикою. Змодельована складна, структурно поширена метафора диригент “піаністів" у Верховній Раді, що має місткий зміст і базується на низці асоціацій, оскільки переосмислення проєктується відразу на кілька музичних термінів - і диригент, і піаніст. Актуалізовано прецедентну ситуацію, що трапилася в залі Верхової Ради України, коли відбувалося голосування, тиск на кнопки іронічно порівнюється з віртуозною грою піаніста.

Прізвища політиків, діяльність яких викликає негативну оцінку, можна продовжити: це Олег Ляшко - лідер радикальної партії. Його називають невгамовний позафракційний баритональний бас, актуалізуючи музичний термін баритональний бас, напр.: Хоча хто 6 сумнівався, якщо поруч кружляв невгамовний позафракційний баритональний бас Олег Ляшко (УП, 08.12.2011). 
Перифразовують й ім’я відомої української співачки й колишнього політичного діяча, члена українського уряду початку XXI ст. періоду правління Президента Віктора Ющенка Оксану Білозір, що була хресною матір'ю президентської дитини, - відома «Зеленим житом» співачка. Прецедентність у цьому разі мотивована наведенням фрагменту української пісні, яку часто виконувала співачка, - «Зеленеє жито, зелене...», напр.: Оксана Білозір - кумася гаранта... і відома «Зеленим житом» співачка... (ПУ, 11.01.2006).

В українському публіцистичному дискурсі з'явилися метафоричні вислови для номінації революцій XXI століття, що відбувалися в українському суспільстві, де актуалізується лексема музика з іронічним семантичним наповненням: музика української революиії - 'про заклики політиків-активістів Помаранчевої революції, що не здійснилися', напр.: Помаранчевий квартет - музика української револющіi (CI, 60). Музичний термін багатоголосся, що має значення 'одночасне звучання кількох голосів', набуває негативної оцінки у вислові фанфари корупційного багатоголосся - 'про проблему масової корумпованості в Україні' (назва статті: Фанфари корупційного багатоголосся - CI, 188). Іноді в межах одного вислову метафоризуються відразу два музичні терміни, напр., квартет і музика (див. вище), а також арія й опера. Порівн.: арія з опери "Коалічійний уряд» - ‘про розкриття справжніх намірів політичної коаліції, напр.: Арія з опери «Коаліційний уряд». Політична інструкиія Сергія Тігіпка дає йому змогу провадити успішну кар'єру з видом на Банкову (CI, 19). Створено іронічну метафору-перифразу. Музичний термін арія вжито в іронічному сенсі й у вислові арія Президента - 'про те, що Президент задоволений фактом прийняття бюджету', напр.: Арія Президента. На момент затвердження «загальний кошторис» гаранта радував (CI, 19).

Поза всяким сумнівом, музичні терміни й в українсько-, і в російськомовних газетних текстах активно детермінізуються, піддаючись метафоризації на основі актуалізованого ланцюжка асоціацій. На метафору може накладатися метонімія, моделюється мовна гра, актуалізуються прецедентні вислови. Для породження метафоричних смислів важливу роль відіграють екстралінгвальні чинники, тобто події, які відбуваються в політичному житті суспільства, що було продемонстровано низкою проаналізованих прикладів. Наведено 
зразки вербалізації соціально-психологічного феномена імені політиків, що мотивовано актуалізацією первинних асоціативних зв'язків, які виникають у свідомості мовців.

\section{Висновки}

Отже, наприкінці XX - на початку XXI століть відбуваються значні мовні зміни, що найбільш яскраво виявляється в дискурсі газети. Це потребує серйозного й систематичного дослідження. Саме газета відбиває рівень духовності народу, особливості його ментальності, мислення, зокрема й політичного, соціально-культурні інтереси, спосіб життя, діяння, наміри й плани, тому й сформувався в сучасному мовознавстві самостійний науковий напрям - медіалінгвістика.

Газетний дискурс, з одного боку, відтворює мовну свідомість сучасних українців, а з другого, - оригінальна лінгвокреативність журналістів впливає на формування мовної свідомості читачів, демонструє зразки смисло- та словотворчості, що грунтуються на системі асоціацій, національній ментальності, важливих соціальних і політичних чинниках.

Комбінаторність лексичних одиниць, поширених у газеті, на семантичному рівні зумовлена серед інших чинників і набором наївних стереотипних уявлень про предмет. Під час утворення стереотипних мовних одиниць із яскравим оцінним компонентом актуалізуються ознаки, закріплені, як доводить проаналізований матеріал, насамперед у побутовій свідомості мовця, що базується переважно на первинних асоціаціях, а не на фонді глибоких енциклопедичних знань.

Використання засобів вторинної номінації можна вважати постійною тенденцією, що демонструє прагнення до посиленої експресивності, згущення інформації, до атракційності медіатексту, репрезентує напрями асоціативного мислення.

Змодельовані в газетному дискурсі медіаобрази, зокрема й метафоричні номінації політиків, шляхи перифразування їхніх імен це соціально-психологічний феномен, який репрезентує систему характеристик і якостей особистості, що заснована на сукупності дискурсивних медіафрагментів, сформованих у мовній практиці, усталених універсальних і національних стереотипах, які мотивовані ланцюжком типових асоціацій людської психіки. Мовні моделі, створені на стереотипах, асоціаціях, належать до ефективних засобів 
маніпуляції мовною свідомістю, налаштовують на певне сприйняття й оцінювання довкілля, зокрема й політичної дійсності.

Українські журналісти демонструють фаховість, знання людської психології, впливають на емоції й почуття читачів, формують активну громадську позицію, а це дуже важливо в умовах гібридної війни, складником якої $є$ війна інформаційна.

Завдання творців газетного дискурсу - зробити його виразним, яскравим і переконливим, що вони успішно, як видається, й реалізують. На основі актуальних асоціацій образні засоби мови газети, як бачимо, постійно оновлюються, модернізуються, але вони завжди зрозумілі й прозорі. Метафоризації підлягає ввесь лексичний пласт

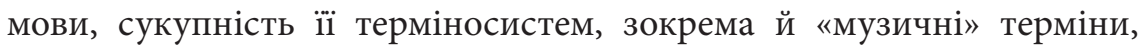
що потребує постійного дослідження з метою більшої репрезентації мовної картини світу українського етносу, демонстрації вектору цього процесу, що й становить перспективу цього дослідження.

\section{Використані джерела та прийняті скорочення}

«Голос України» - ГУ; «Новая газета» - НГ; «Україна молода» - УМ; «Українська правда» - УП; «Сіверщина» - С.; «Слово просвіти» - СП; «Like»; «Комсомольская правда» - КП; «Известия» - И.; «Труд» - Т.; «Обозреватель» - О.; «Rossijskaya gazeta» - PГ; «Trud» - T.; «Obozrevatel'» - O.

\section{ЛІТЕРАТУРА}

1. Арутюнова, Н. Д. (1990). Метафора и дискурс. В Арутюнова, Н. Д. Теория метафоры (с. 5-32). Москва: Прогресс. 2. Бартминьский, Е. (2009). Базовые стереотипы и их профилирование на материале польского языка. В Федорова, Л. Д. (Ред.). Стереотипы в языке, коммуникаичии и культуре (с. 11-21). Москва: РГГУ. 3. Бартминьский, Е. (2005). Языковой образ мира: очерки по этнолингвистике. Москва: Индрик. 4. Валгина, Н. С. (2001). Активные процессы в современном русском языке. Москва: Логос. 5. Ільченко, О. А. (2012). Вербалізоване «обличчя» сучасного суспільства: словник метафборичних сполучень української преси (2000-2010рр.). Харків: Нац. акад. Нац. гвардії України. 6. Космеда, Т. (2000). Аксіологічні аспекти прагмалінгвістики: формування і розвиток категорії оцінки. Львів: ЛНУ ім. І. Франка. 7. Космеда, Т. (2014а). Актуальні процеси мовлення чи «мовний смак» української сучасності. Мовознавство, 2, 44-55. 8. Космеда, Т. (2014b). Антропонимная метафора публицистического текста как лингвокреативная реакция на актуальные события действительности (на материале русского и украинского языков). W Mampe, J., \& Owczinnikowa, Ł. (Red.). Socjolingwistyczne badania w teorii i praktyce. (T. 1). (Str. 83-93). Gdańsk: Wyd-wo Un-tu Gdańskiego. 9. Космеда, T. (2017). Лингвокалейдоскоп: живые речевые процессы. Саарбрюккен: Изд. дом Lambert Academic Publishing. 10. Кульпина, В. Г. (2002). Психолингвистический анализ в реконструкции исторических личностей (имена, вторичные имена, прозвища Наполеона в России и Польше). 
Мир психологии, 3 (31), 176-196. 11. Солганик, Г. Я. (Ред.). (2012). Язык СМИ и политика. Москва: Изд-во Москов. ун-та; Ф-т журналистики МГУ имени М. В. Ломоносова. 12. Степаненко, М. (2017). Політичне сьогодення української мови: актуальний перифрастикон. Харків: Вид. Іванченко І. С. 13. Степаненко, М. (2018). Публіцистично-політичні перифрази в українській мові: 2017 рік. Полтава: Дивосвіт. 14. Чернявская, В. Е. (2017). Дискурс власти и власть дискурса: проблемы речевого воздействия. Москва: Флинта: Наука. 15. Шевченко, Л. І. (2014). Медіалінгвістика в сучасній Україні: аналіз ситуації. В Дергач, Д. В., \& Сизонов, Д. Ю. (Уклад.). Лариса Іванівна Шевченко: горизонтами модерної лінгвістики (с. 169-175). Київ: ВПЦ “Київ. ун-т".

\section{REFERENCES}

1. Arutyunova, N. D. (1990). Metafora i diskurs [Metaphor and discourse]. In Arutyunova, N. D. Teoriya metafory - Metaphor theory (pp. 5-32). Moskva: Progress [in Russian]. 2. Bartmin'skij, E. (2009). Bazovye stereotipy i ix profilirovanie na materiale pol'skogo yazyka [Basic stereotypes and their profiling based on the material of the Polish language]. In Fedorova, L. D. (Red.). Stereotipy v yazyke, kommunikacii $i$ kul'ture - Stereotypes in language, communication and culture (s. 11-21). Moskva: RGGU [in Russian]. 3. Bartmin'skij, E. (2005). Yazykovoj obraz mira: ocherki po e'tnolingvistike [Linguistic Image of the World: Essays on Ethnolinguistics]. Moskva: Indrik [in Russian]. 4. Valgina, N. S. (2001). Aktivnye processy $v$ sovremennom russkom yazyke [Active processes in modern Russian]. Moskva: Logos [in Russian]. 5. Ilchenko, O. A. (2012). Verbalizovane «oblychchia» suchasnoho suspilstva: slovnyk metaforychnykh spoluchen ukrainskoi presy (2000-2010 rr.) [Verbalized "face" of modern society: a dictionary of metaphorical combinations of the Ukrainian press (2000-2010)]. Kharkiv: Nats. akad. Nats. hvardii Ukrainy [in Ukrainian]. 6. Kosmeda, T. (2000). Aksiolohichni aspekty prahmalinhvistyky: formuvannia i rozvytok katehorii otsinky [Axiological aspects of pragmalinguistics: formation and development of the category of assessment]. Lviv: LNU im. I. Franka [in Ukrainian]. 7. Kosmeda, T. (2014a). Aktualni protsesy movlennia chy «movnyi smak» ukrainskoi suchasnosti [Actual processes of speech or "language taste" of Ukrainian modernity]. Movoznavstvo - Linguistics, 2, 44-55 [in Ukrainian]. 8. Kosmeda, T. (2014b). Antroponimnaya metafora publicisticheskogo teksta kak lingvokreativnaya reakciya na aktual'nye sobytiya dejstvitel'nosti (na materiale russkogo i ukrainskogo yazykov) [An anthroponymic metaphor of a publicistic text as a linguistic and creative reaction to actual events in reality (based on the material of the Russian and Ukrainian languages)]. In Mampe, J., \& Owczinnikowa, Ł. (Ed.). Socjolingwistyczne badania w teorii i praktyce - Sociolinguistic research in theory and practice. (T. 1). (pp. 83-93). Gdańsk: Wyd-wo Un-tu Gdańskiego [in Russian]. 9. Kosmeda, T. (2017). Lingvokalejdoskop: zhivye rechevye processy [Lingvocaleidoscope: living speech processes]. Saarbryukken: Izd. dom Lambert Academic Publishing [in Russian]. 10. Kul'pina, V. G. (2002). Psixolingvisticheskij analiz v rekonstrukcii istoricheskix lichnostej (imena, vtorichnye imena, prozvishha Napoleona $\mathrm{v}$ Rossii i Pol'she) [Psycholinguistic analysis in the reconstruction of historical figures (names, secondary names, nicknames of Napoleon in Russia and Poland)]. Mir psixologii - World of psychology, 3 (31), 176-196 [in Russian]. 11. Solganik, G. Ya. (Ed.). (2012). Yazyk SMI i politika [Media language and politics]. Moskva: Izd-vo Moskovskogo un-ta; F-t zhurnalistiki MGU imeni M. V. Lomonosova [in Russian]. 12. Stepanenko, M. (2017). 
Politychne sohodennia ukrainskoi movy: aktualnyi peryfrastykon [The political present of the Ukrainian language: the current periphrasticon]. Kharkiv: Vyd. Ivanchenko I. S. [in Ukrainian]. 13. Stepanenko, M. (2018). Publitsystychno-politychni peryfrazy v ukrainskii movi: 2017 rik [Journalistic and political paraphrases in the Ukrainian language: 2017]. Poltava: Dyvosvit [in Ukrainian]. 14. Chernyavskaya, V. E. (2017). Diskurs vlasti i vlast' diskursa: problemy rechevogo vozdejstviya [Discourse of power and the power of discourse: problems of speech impact]. Moskva: Flinta: Nauka [in Russian]. 15. Shevchenko, L. I. (2014). Medialinhvistyka v suchasnii Ukraini: analiz sytuatsii [Medialinguistics in modern Ukraine: situation analysis]. In Derhach, D. V., \& Syzonov, D. Iu. (Eds.). Larysa Ivanivna Shevchenko: horyzontamy modernoi linhvistyky - Larysa Ivanivna Shevchenko: horizons of modern linguistics (pp. 169175). Kyiv: VPTs "Kyiv. Un-t" [in Ukrainian].

Космеда Тетяна Анатоліївна - доктор філологічних наук, професор, професор кафедри україністики Інституту російської й української філології, Університет імені Адама Міцкевича; ал. Незалежності, 4, м. Познань, Польща, 61-874.

Tel.: +38-050-516-82-11

E-mail: tkosmeda@gmail.com

https://orcid.org/0000-0001-8912-2888

Kosmeda Tetiana Anatoliivna - Doctor of Philological Sciences, Professor, Professor of the Department of Ukrainian Studies, Institute of Russian and Ukrainian Philology, Adam Mitskevych University; Al. Niepodległości 4, Poznań, 61-874, Poland.

Надійшла до редакції 17 листопада 2020 року

\section{CITATION}

ДСТУ 8302:2015: Космеда Т. А. Вербалізація соціально-психологічного феномена медіаобразів у дискурсі сучасної українсько- й російськомовної газети: актуалізація асоціативних зв'язків. Лінгвістичні дослідження: зб. наук. пр. Харк. нац. пед. ун-ту імені Г. С. Сковороди. Харків, 2021. Вип. 54. Ч. I. С. 89-102. DOI: https://doi.org/10. 34142/23127546.2021.54.1.08

AРA: Космеда, Т. А. (2021). Вербалізація соціально-психологічного феномена медіаобразів у дискурсі сучасної українсько- й російськомовної газети: актуалізація асоціативних зв'язків. Лінгвістичні дослідження, 54 (I), 89-102. DOI: https://doi.org/10. 34142/23127546.2021.54.1.08 